Asian Journal of Agricultural Sciences 6(1): 16-32, 2014

DOI:10.19026/ajas.6.4850

ISSN: 2041-3882; e-ISSN: 2041-3890

(C) 2014 Maxwell Scientific Publication Corp.

Submitted: October 19, $2013 \quad$ Accepted: October 28, $2013 \quad$ Published: January 25, 2014

\title{
Research Article \\ The Influence of Institutional Factors on the Adoption of Integrated Natural Resource Management Technologies by Small Scale Farmers in South Western Kenya
}

\author{
Isaiah K. Okuthe \\ Ministry of Energy, Kenya
}

\begin{abstract}
The aim of the study was to examine the influence of institutional factors on the adoption of integrated natural resource management technologies by small scale farmers in Ndhiwa division, Kenya. Soil fertility depletion and the corresponding declining agricultural productivity in Kenya's Ndhiwa division have led to many attempts to develop and popularize Integrated Natural Resource Management (INRM) technologies that could restore soil fertility. INRM bridges the gap between high external input agriculture and extreme forms of traditional low external input agriculture. The main components of INRM in Ndhiwa division are chemical fertilizer, animal manure, green manure, stover lines and agro forestry. However the adoption of these technologies appears to be low resulting to probably the low production. It is not understood well why farmers who rely on agriculture for their livelihoods, either do not adopt or adopt the technologies and then abandon them. However it is acknowledged that soil depletion is a serious and slow process hence the determinants of the adoption of INRM technologies are critical. An ex-post-facto survey design which utilized both qualitative and quantitative methods of data collection was used in the study. For quantitative data collection, a sample of 220 small scale farmers selected using systematic random sampling from the small scale farmers in the Division were engaged. For qualitative data, 40 small scale farmers and 37 Key Informants selected using purposive sampling from the division were used. Results of the study indicated that land tenure, access to credit, access to inputs, access to market, mass media exposure and contact with extension were important variables which had positively and significantly influenced adoption of INRM technologies. The overall finding of the study underlined the high importance in strengthening social groups to enhance adoption of INRM technologies. The study will be significant to planners, policy makers, researchers, extension and farmers to build the case for interventions on INRM within the development sector for improved and sustainable agriculture and rural development.
\end{abstract}

Keywords: Adoption, integrated natural resource management technologies, small scale farmer

\section{INTRODUCTION}

The continued threat to the world's natural resources is exacerbated by the need to reduce poverty and unsustainable farming practices. A significant proportion of the rural population of Sub-Saharan Africa (SSA) is food insecure and malnourished. Food security is one of the main global concerns in many developing countries (FAO, 1986; IFAP, 1995). Food insecurity is most acute in sub -Sahara Africa., where the attainment of food security is intrinsically linked with reversing stagnation and safeguarding the natural resource base (IFAP, 1995). Declining soil fertility and low nutrient levels is recognized as one of the major biophysical impediment to agricultural growth of African agriculture (Nye and Greenland, 1960; FAO, 1986; Pieri, 1989; Yates and Kiss, 1992; Vanleuw and Giller, 2006).

Recent estimates indicate that by the year 2020, the SSA annual cereal imports will rise to more than 30 million metric tons, as the per-capita food production continues to decline against a background of rapidly growing population estimated at 3\% per annum. This failure to match food supply to demand is mainly attributed to soil nutrient depletion following intensification of land use without proper land management practices and inadequate external inputs (Sanchez et al., 2001). The low soil fertility arises due to:

- Breakdown of the erstwhile traditional natural fallow system that used to be the means of replenishing the soil fertility

- Continuously cultivation of crops without external fertilizer due to the high costs of mineral fertilizers

The need to improve soil management in the continent has become a very important issue in the development policy agenda because of the strong linkage between soil fertility and food insecurity on one hand and the implications on the economic wellbeing of the population on the other hand (Ajayi et al., 2003). Integrated Natural Resource Management is the 
management of soil fertility using multiple practices simultaneously in an integrated fashion in order to exploit the prospective complementarities among different soil management techniques. At the core of the Integrated Soil Fertility Management (ISFM) paradigm is the recognition that no single component of soil fertility management can stand on its own in meeting the requirements of sustainable soil fertility management (Vanlauwe, 2004; Place et al., 2003).

The popularity of INRM based approaches to natural resource management in the USA is reflected in the rise of coast care, land care, regional bodies and other social mobilization approaches to INRM throughout the world. Soil fertility depletion and the corresponding declining agricultural productivity in the world have led to many attempts to develop and popularize INRM technologies that consequently restore soil fertility. INRM bridges the gap between high external input agriculture and extreme forms of traditional low external input agriculture. The main components of INRM practices are fertilizers, manure, improved fallows, agro forestry and green manures. INRM technology has the potential to improve soil fertility through the maintenance increase of soil organic matter and biological Nitrogen $(\mathrm{N})$ fixation from nitrogen fixing tree species (Young, 1997).

Researchers in the USA have introduced INRM as a subsistence option to replenish soil fertility within the shortest possible time (Phiri et al., 2003). Various studies in the world have shown the potential of INRM as an approach to sustainable agricultural production and soil management especially in the tropics. There are some technologies that replenish soil fertility and provide other needs such as fuel wood, hence become integral part of the household subsistence needs. INRM is a sustainable agricultural system with potentials to improve food security and is being promoted in most parts of the USA (Young, 1997). Despite the successes and the increased adoption of INRM in North and South America, the adoption among small scale farmers in Eastern and Southern Africa has been very low (Young, 1997).

In the Philippines, consideration efforts have been committed to research and extension to facilitate the adoption of the hedgerow intercropping, yet a recent report (Young, 1997) described adoption as "sporadic and transient, rarely continuing once external support is withdrawn". This report evaluates the cost-benefit of alternative forms of hedgerow intercropping. However, farmers were more interested in a local adaptation of the technology which includes natural vegetation and grass strips. Another disadvantage was the cost of credit and land tenure security which affects the farmer's planning horizons and the confidence with which they expect to benefit from long term investment in soil conservation.

Smallholder agriculture in much of the low-income tropics is nonetheless characterized by widespread failure to make sufficient soil fertility replenishment and soil conservation investment in order to sustain the quality of farmland (Sanchez et al., 2001; Reardon et al., 2001; Barret et al., 2002; World Bank, 2003). A substantial literature based on cross-sectional analysis has explored the adoption of INRM methods in order to understand the failure to make these critical investments (Sheikh et al., 2003; Phiri et al., 2003; Franzel et al., 2001; Pfister et al., 2005). But there has been little accompanying exploration of the reasons for disadoption of these technologies, especially over a period of many years. Since INRM requires ongoing practice, it is essential to understand both initial adoption and continued application of the methods.

Land productivity in many parts of sub-Sahara Africa is declining (Vanlauwe, 2004; Place et al., 2003). Crop yields for staple food crops such as maize, millet and sorghum oscillate at 1 tonne grain per hectare in small holder rain fed farms in SSA. Furthermore, yield levels in SSA show no clear tendency of increasing over the last 2 generations (Vanlauwe, 2004; Place et al., 2003).

The potentials of INRM as a means of building up soil productivity in the long run and thereby attaining higher yield at lower costs, has been fully acknowledged and picked up by commercial farmers in Zimbabwe and Tanzania operating in degradation sensitive farming landscapes (Place et al., 2003; Vanlauwe, 2004). There are many examples of successful adoption of INRM technologies in Eastern and Southern Africa where crop yields have increased through INRM technologies.

Like in most Sub Sahara African countries, the major constraint to small holder farming in Kenya is the declining soil fertility (Smaling et al., 1993). Small holder farms of about 2 ha on average are usually cultivated continuously without adequate replenishment of plant nutrients resulting in removal of nutrients from soils mainly through crop harvests. An average of maize grain crop yield of less than $500 \mathrm{~kg} / \mathrm{ha}$ has been reported in Western Kenya (Odera et al., 2000). For instance in Western Kenya, which has high population densities exceeding $300 / \mathrm{km}^{2}$, farms are characterized by widespread failure to make sufficient soil fertility replenishment investments, resulting in declining soil fertility, low returns to agricultural investment, decreased food security and general high food prices consequently threatening food security in this region (Odera et al., 2000).

Ndhiwa is one of the 4 divisions of Ndhiwa distict in Western Kenya.. Agronomic and soil science research in the recent years shows that soil nutrient mining, lack of soil conservation measures, monocropping and continuous cropping without external fertilizer is widespread in Western Kenya, undermining the ability of many agrarian households to produce enough food supplies for subsistence (Smaling 
et al., 1993; Van der Bosch et al., 1998; FAO, 2004). For instance, Smaling et al. (1993) report average annual net mining of $42 \mathrm{Kg}$ nitrogen/ha, $3 \mathrm{Kg}$ phosphorus/ha and $29 \mathrm{Kg}$ potassium/ha from the soils in this region. Various.

Studies in the world have shown the potential of INRM as an approach to sustainable agricultural production and soil management especially in the tropics. There are some technologies that replenish soil fertility and provide other needs such as fuel wood, hence become integral part of the household subsistence needs. INRM is a sustainable agricultural system with potentials to improve food security and is being promoted in most parts of the world (Okuro et al., 2002).

The main objective of this study was to examine the influence of institutional factors on the adoption of integrated natural resource management technologies in Ndhiwa district.

This study also provides a useful input for the development of training materials for extension staff that are critical in the transfer of agricultural technology. Besides, the study also provide insight into whether and how external assistance can be used more effectively to enable smallholder households to secure their basic needs, promote self-reliance and adopt sustainable INRM technologies as a means of breaking the cycle of natural resource degradation to ensure agricultural/environmental sustainability and eradicate extreme poverty and hunger (MDGs nol and no7) in this households.

The findings from the study may also be used by researchers, planners and policy makers to build the case for more focused planning for interventions on INRM within the development sector and also contribute to knowledge in the area of natural resource management.

\section{RESEARCH METHODOLOGY}

The study area: The study was carried out in Ndhiwa Division of Ndhiwa District. It is one of the four divisions in Ndhiwa District, located in the southwestern part of Kenya along Lake Victoria. It is located between longitude $34^{\circ} 12^{\prime}$ and $34^{\circ} 40^{\prime}$ east and latitudes $0^{\circ} 28^{\prime}$ and $0^{\circ} 40^{\prime}$ south (Government of Kenya, 2001a). Ndhiwa is inhabited mainly by the Luo community. The division has a population of approximately 115,122 , with an annual growth of $2.7 \%$. The division has a mean density of 270 persons per $\mathrm{km}^{2}$ but the distribution within the division is influenced by the availability of road infrastructure and climate (Government of Kenya, 2001a). The female/male sex ratio is $100 / 110$ with the youth and labour force comprising 23 and $47.8 \%$, while the dependency ratio is $100: 110$. The Division is further sub divided into 4 locations and 11-sub -locations. It has a population of 43,231 small scale farmers (Government of Kenya, 2001a). According to Jaetzold and Schmidt (1982), the division lies in lower midland $(\operatorname{lm} 3)$ agro-ecological zone. It is situated at an altitude of $1200-1400 \mathrm{~m}$ above seal level. The mean rainfall is about $1300 \mathrm{~mm}$ received in a bimodal pattern. The Division has three types of soils; black cotton soil (vertisol), silt loam, clay loam (luvisoils) with drainage being poor in some of the soils (Jaetzold and Schmidt, 1982).

Agriculture is the lifeline of the division's economy employing over $50 \%$ of the residents. Smallholder farming is the dominant land use practice accounting for about $86.8 \%$ of land cultivated in the division (Government of Kenya, 2001a). The cultivation of food crops is dominated by maize, sorghum and bean production (Government of Kenya, 2001a). The annual cereal production in 2000 was 41,520 tones as compared to its cereal demand of 41,819 tones.

The high use of firewood and charcoal contributes to deteriorating tree and vegetation cover exposing the soil to severe degradation especially on hill tops, a trend that threatens future livelihood activities. Agronomic and soil science research in recent years has shown that soil nutrient mining, monocroping and continuous cropping is widespread in Ndhiwa division, undermining the ability of many agrarian households to produce enough food supplies for subsistence (Smaling et al., 1993; Van der Bosch et al., 1998; FAO, 2004). For instance, Smaling et al. (1993) report average annual net mining of $42 \mathrm{~kg}$ nitrogen/ha, $3 \mathrm{~kg}$ phosphorus/ha and $29 \mathrm{~kg}$ potassium/ha from the soils in this region (Fig. 1).

Sources of data: The study used both qualitative and quantitative data collection techniques. The data collection tools included.

Questionnaires: Questionnaires were administered to the first sub-category (220 small scale farmers) selected for the study. Questionnaires were considered ideal because of the ease of administration and scoring of the instrument besides the results being readily analyzed (Ary et al., 1979). The items on the questionnaire were developed on the basis of the objectives of the study. The questionnaire captured data on the sociodemographic characteristics of the respondents, the degree of adoption of INRM technologies, socioeconomic determinants of the adoption of INRM technologies, socio-cultural determinants of the adoption of INRM technologies and the institutional determinants of the adoption of INRM technologies.

In-depth Interviews: Semi-structured interview schedule guidelines with relevant questions were developed for the $37 \mathrm{key}$ informants. The semistructured interview schedule was considered 
appropriate for extension officers from the Ministry of Agriculture and opinion leaders because they have varied literacy levels. Some of them were not able to interpret and react to a questionnaire. Thus the semistructured interview schedule was used to obtain indepth information from the extension officers and opinion leaders regarding their opinion on the determinants of the adoption of improved NRM practices in Ndhiwa division.

Focus group discussion: Focus Group Discussion (FGD) guideline was developed for the 40 small scale farmers. A total of four FGDs were held. FGDs were important in obtaining information that could not be easily obtained through face-to-face interview or questionnaire. For this method, the researcher brought together forty small scale farmers in four groups, to discuss the topic. Atopic guide to aid discussion was prepared beforehand and a range of aspects of the topic will be explored. Brainstorming techniques were used to explore the topic.

Observations: To get a greater picture of INRM technologies, a checklist was developed for observations to be made. Data was collected by the researcher so that a detailed understanding of the values and beliefs held by the members of the population can be understood. Observations were done to gather evidence about how value judgments made by extension staff and farmers impact on decision making. Observation were recorded as field notes and analyzed for content.

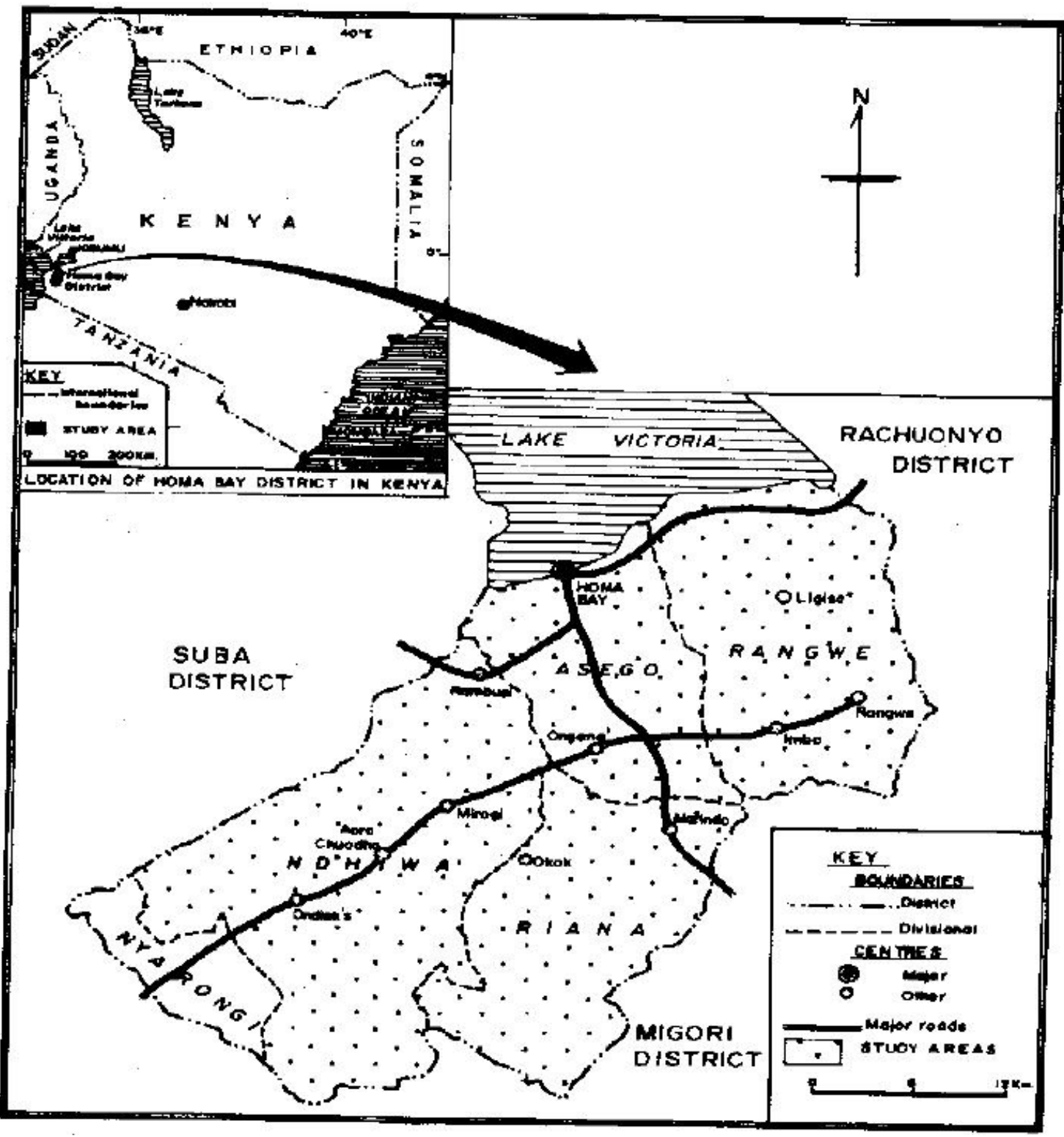

Fig. 1: Location map of the study area 
Sample size and sampling procedure: The sampling frame was a list of 43, 231 small scale farmers from Ndhiwa District Development Offices for the respective division. The sample size was obtained using the coefficient of variation (Nassiuma, 2000). This is because for most surveys or experiment, a coefficient variation of at most $30 \%$ is usually acceptable. The study took a coefficient variation of $21 \%$ and a standard error of 0.02 . The equation given by Nassiuma (2000) is:

$$
\mathrm{n}=\frac{\mathrm{NC}^{2}}{\mathrm{C}^{2} 2+(\mathrm{N}-1) \mathrm{e}^{2}}
$$

where,

$\mathrm{n}=$ Sample

$\mathrm{N}=$ Population

$\mathrm{C}=$ Covariance

e $=$ Standard error

The number of households for Ndhiwa division will be:

$$
\mathrm{n}=\frac{43231 \times(21 \%)^{2}}{(21 \%)^{2}+(43231)(0.02)^{2}}=220 \text { households }
$$

The four locations of the small scale farmers was the criterion for stratified proportionate random sampling. All the small scale farmers in the four locations were used to enable random selection of households to be included in the study. A systematic random sampling procedure was used to select the number of households in each stratum. Purposive sampling technique was applied to identify individuals to participate in the focus group discussion and Key informants to be interviewed. A total of 40 small scale farmers were purposively selected to participate in the four FGDs.

From each location, three categories of target group, viz the small scale farmers, Ministry of Agriculture Officers and opinion leaders were targeted. Among the Ministry of Agriculture target category, one Divisional Agriculture Extension Officer, five subject matter specialists from Ndhiwa division and one location Agricultural Extension Officer from each location yielding a total of seventeen Ministry of Agriculture officers. From the third category of opinion leaders (1 Do, 4 chiefs, 11 assistant chiefs and 4 councilors) were selected yielding twenty opinion leaders. They supplemented the information from the small scale farmers. The entire sampling matrix yielded a total sample size of 297 for the proposed study. The sampling by location of small scale farmers is shown in Table 1.

Data analysis: All the data collected from the study area as in the questionnaires, FGDs, in depth interviews and observation reports were analyzed in an ongoing process. Quantitative data was processed, coded and
Table 1: Sampling by location in Ndhiwa Division, Ndhiwa District

\begin{tabular}{llll}
\hline Locations & Farmers & Population & Sample \\
\hline North Kanyamwa & 9880 & 0.24 & 50 \\
South Kanyamwa & 12700 & 0.30 & 65 \\
Central Kanyamwa & 8700 & 0.21 & 45 \\
West Kanyamwa & 11751 & 0.28 & 60 \\
Total & 43231 & 1.00 & 220 \\
\hline
\end{tabular}

analyzed using computer statistical packages (S.P.S.S version 13). The results were presented by use of descriptive statistics, namely percentages and frequencies. Qualitative data will be transcribed and subsequently themes and sub-themes derived. The themes and subthemes were then presented as they emerged.

Ethical consideration: The study was conducted in accordance with the standard research ethics. Informed consent was sought prior to data collection. Anonymity and confidentiality was also upheld. An appointment for administration of questionnaires to the respondents was prepared with the assistance of the village headmen. The principal researcher guided and supervised the fieldwork during data collection. The instruments were then administered to household heads to collect the required data in face-to-face interview and their responses recorded accordingly.

\section{RESULTS AND DISCUSSION}

Adoption of integrated natural resource management technologies: The study focused on four INRM technologies. These were the use of stover/trash lines for nutrient recycling, agro forestry for nutrient replenishment using woody species, use of livestock manure and use of inorganic chemical fertilizers. Stover (trash/lines are heaps of stover and other biodegradable crop detritus and farm (and off-farm) plant debris that the farmer places across the plot contour (s).

To determine the level of adoption of INRM technologies farmers were asked to respond to a set of ten questions on degree of adoption of INRM technologies. The questions were based on use of fertilizer and manure, agro forestry and stover lines. The results obtained indicated that out of the 210 respondents 55 farmers $(54.2 \%)$ used manure, 22 farmers $(21 \%)$ practiced agro forestry and 10 farmers $(9.5 \%)$ had stover lines in their farms while 16 farmers $(15.3 \%)$ used fertilizer. On the other hand the remaining $115(52.3 \%)$ had not adopted any of these technologies. Table 2 presents results of how farmers adopted INRM technologies.

From the Table 2, it was noted that out of the four INRM technologies studied, it was only the use of manure that could be judged as the most significantly adopted by the respondents, where $(54.2 \%)$ of the respondents had fully adopted the practice. It is to be recognized that all the respondents were aware and interested to use manure but not all did. The respondents indicated that even though they were 
interested in using manure, the technology was not always available and when it became available, it was limited in quantity and consequently, it would not within the reach of most poor rural farmers.

The use of fertilizer was also known to all (100\%) of the respondents while only a few $(15.3 \%)$ of the respondent respondents eventually adopted the technology. It was noted here that the non significant adoption of this technology could be attributed to non ready availability of the fertilizer and lack of affordability on the part of the respondents due to high cost. During group discussion most farmers expressed that none of them had used fertilizer and stover lines.

Similar reasons were adduced for non significant use of agro forestry where only $10 \%$ respondents adopted and as majority were aware of the technology. The table also shows that the use of stover lines was only adopted by $10(9.5 \%)$ respondents. This indicates low adoption rates for these technologies. All the practices as a complete package were adopted by only $11.9 \%$ of the respondents. It was observed that in all the INRM technologies studied, the respondents were more aware, interested and tried them than they adopted them. This goes to prove that awareness of technology, interest in it and even trial do not automatically guarantee adoption. There could be other factors that interfere with adoption of these technologies.

Farmer's interest in adopting new practices may be constrained by inadequate information about that particular innovation, which may in part be caused by inability of the extension personnel to reach the farmers. It has been reported that most farmers stick to old practices as result of economic inability on the part of the farmers to afford the cost of innovations, risk involved, ignorance of existence of innovations and their attitude (Wasula, 2000). Non adoption of some of these technologies could be as a result of high prices, relative scarcity and poor presentation of the technologies to farmers, unavailability of the technologies and inability of extension agents to facilitate their adoption.

During focus group discussion farmers pointed out that, use of stover lines in the field is impossible due to its additional labor and time requirement. They also pointed out that fertilizer was expensive and hence low adoption of this.

Key informants from the sampled institutions cited the rising cost of the rising cost of fertilizer and tree seedlings as a major budgetary constraint. "Everything is going up in price, even fertilizer and tree seedlings are very expensive these days". Similarly, key informants from the sampled institutions cited additional labor and time requirement for use of stover lines in the farms.

FGD results also indicated that people are aware of the technologies like fertilizer and agro forestry but such technologies are priced out of their reach. Even in
Table 2: Adoption of INRM technologies

\begin{tabular}{lll}
\hline Technology & Frequency & Percentage \\
\hline Manure use & 55 & 54.2 \\
Stover lines & 10 & 9.5 \\
Agro forestry & 22 & 21 \\
Fertilizer use & 16 & 15.3 \\
Total & 105 & 100 \\
\hline
\end{tabular}

Table 3: Land ownership status by farmers

\begin{tabular}{lll}
\hline Monthly income & Adopters $(\mathrm{n}=105)$ & $\begin{array}{l}\text { Non-adopters } \\
(\mathrm{n}=115)\end{array}$ \\
\hline Communal & $18(17.1 \%)$ & $30(26.1 \%)$ \\
Private & $84(80 \%)$ & $85(73.9 \%)$ \\
Rented & $3(2.9 \%)$ & $0(0 \%)$ \\
Total & $105(100 \%)$ & $115(100 \%)$ \\
\hline
\end{tabular}

relatively better off regions only a few participants said they use fertilizer and agro forestry. A woman FGD participant from one cluster said "we long to use fertilizer but we cannot afford". In some cases FGD participants expressed awareness of the INRM technologies but cited lack of information on whether such technologies are affordable or easily accessible.

Institutional factors determining adoption of INRM technologies by small scale farmers: The farmers were asked to respond to a set of questions on the institutional factors that have influence on the adoption of INRM technologies. The factors included land tenure, access to credit, source of inputs, membership in social groups, access to market and contact with extension.

Land tenure: Land is the main asset owned by farmers in the study area. Farmers in the study area use both their own land and also rent land for crop production. Land tenure provides farmers with full rights of land ownership and usage thus influencing the decision to participate in natural resource management. Land ownership with title deeds accords the farmers the right to usage (security of tenure) thus creating an incentive to farmers to adopt new, long term and even riskier technologies (Rahmeto, 2007).

Table 3 shows that a significant majority (over $80 \%$ ) of the respondents owned land privately but the level of adoption of these technologies was still low. Only a minority (2.9\%) rented land. These findings concur with those found by Rahmeto (2007) where land ownership did not seem to have a significant effect on the adoption of agro forestry systems in Ethopia. According to Rahmeto (2007) what seemed important was how farmers feel about their property with or without the land ownership. The results of this study are also in harmony with the findings of Mugeta (2000), Yishak (2005) and Mesfin (2005).

Access to credit: Adoption of INRM technologies by farmers is motivated by the income gained from the sale of the produce. Farmers grow crops not for 
consumption purpose only but to fetch cash income which is allocated for purchasing farm inputs and meet other family needs (Rahmeto, 2007). But constraints to adoption of INRM technologies are numerous: the cost of fertilizer, high labor requirement and technical skill need for INRM technologies management, are some of the constraints that hinder the adoption of this technologies (Rahmeto, 2007). Access to credit is way of improving farmers' access to new technology. Farmer's ability to purchase inputs such as improved seed and fertilizer is particularly important. The formal sources of credit in Kenya are Cooperative societies, saving and credit societies, banks, self-help groups and farmer's organizations. Farmers who have access to credit can minimize their financial constraints and buy inputs more readily (Rahmeto, 2007). The result on credit accessibility by respondents is summarized and presented in Table 4.

According to Table 4, eighty six $(81.9 \%)$ out of 105 adopters had not used credit as compared to $(18.1 \%)$. This was the reason for the low adoption of the technologies by the respondents. This showed that there was a significant relationship between access to credit and adoption of INRM technologies. This finding concurs with Reardon et al. (2001) where only 5\% of the progressive farmers obtained loans.

This is disadvantageous to farmers who operate on a small scale level and are less influential to the credit sector. Poor credit conditions may also be another reason that suppresses the capacity to adopt an innovation (Legesse, 1992; Teressa, 1997). Although credit may appear quite rational to a farmer, social forces outside his control dictate his propensity to adopt the technology. The optimal effective INRM technologies require cash for labor that is used in constructing stover/trash lines, planting trees and purchase of chemical fertilizer. Credit therefore is a strong facilitator in enhancing effective access to INRM technology. Farmers without cash and no access to credit will find it very difficult to adopt new technologies. Previous authors verified this preposition (Legesse, 1992; Teressa, 1997). It is expected that access to credit will increase the probability of adopting INRM technologies (Legesse, 1992; Teressa, 1997).

Access to quality inputs: Input delivered by an institution will have its own impact on adoption of a given technology and production and productivity of crops (Ndiema, 2002). With this understanding data on problems of input delivered by organizations and purchased from market were collected and summarized as in Table 5.

According to Table 5, eighty (76.2\%) out of 105 adopters had not used quality inputs as compared to twenty five (23.8\%). Majority of respondents reported delay and poor quality of INRM technologies as problem of inputs. Furthermore majority of respondents
Table 4: Access to credit by farmers

\begin{tabular}{lll}
\hline Use of credit & Adopters $(\mathrm{n}=105)$ & $\begin{array}{l}\text { Non-adopters } \\
(\mathrm{n}=115)\end{array}$ \\
\hline Yes & $19(18.1 \%)$ & $10(8.7 \%)$ \\
No & $86(81.9 \%)$ & $105(91.3 \%)$ \\
Total & $105(100 \%)$ & $115(100 \%)$ \\
\hline
\end{tabular}

Table 5: Access to inputs by farmers

\begin{tabular}{lll}
\hline Access to inputs & Adopters $(\mathrm{n}=105)$ & $\begin{array}{l}\text { Non-adopters } \\
(\mathrm{n}=115)\end{array}$ \\
\hline Yes & $25(23.8 \%)$ & $10(8.7 \%)$ \\
No & $80(76.2 \%)$ & $105(91.3 \%)$ \\
Total & $105(100 \%)$ & $115(100 \%)$ \\
\hline
\end{tabular}

Table 6: Access to market by farmers

\begin{tabular}{lll}
\hline Access to market & Adopters $(\mathrm{n}=105)$ & $\begin{array}{l}\text { Non-adopters } \\
(\mathrm{n}=115)\end{array}$ \\
\hline Subsistence & $77(73.3 \%)$ & $86(73.9 \%)$ \\
Commercial & $28(26.7 \%)$ & $30(26.1 \%)$ \\
Total & $105(100 \%)$ & $115(100 \%)$ \\
\hline
\end{tabular}

reported delay and expensiveness of fertilizer as problems of inputs. This implies importance of time, quality and price in input delivery. This could have been the reason for the low adoption of the technologies. This showed that there was a significant relationship between access to credit and adoption of INRM technologies. This finding concurs with Reardon et al. (2001) where only $5 \%$ of the progressive farmers obtained inputs from reputable source. This is disadvantageous to farmers who operate on a small scale level and are less influential to the input and credit sector (Rahmeto, 2007).

Poor input sources may also be another reason that suppresses the capacity to adopt an innovation (Ndiema, 2002). Although inputs from reputable source may appear quite rational to a farmer, social forces outside her control dictate his propensity to adopt the technology. The optimal effective INRM technologies require inputs from reputable sources (Ndiema, 2002). Inputs therefore are a strong facilitator in enhancing effective access to INRM technology. Focus group discussion with farmers reported delay and poor quality seedlings and expensive fertilizer as problems of accessing inputs by farmers. Key informants also reported increasing trend on seedlings, labor and fertilizer price.

Access to market: Markets are common centers both for producers, consumers and traders (Tadesse and Belay, 2007). In this study, it was hypothesized that access to market and distance between the respondents' residence and the nearest market place (measured in kilometers) will positively influence the respondents' decision to adopt newly introduced technologies.

Table 6 shows that a significant majority $(73.3 \%)$ of the adopters utilized their farm produce for subsistence. Beside the distance taken to travel from home to the nearest market was an average of $10 \mathrm{~km}$. For sample respondents the minimum and maximum distance that a farmer had to travel to access market 
center were $2 \mathrm{~km}$ and $30 \mathrm{~km}$, respectively. This means that they could not access the market easily. Only a minority $(26.7 \%)$ used their produce for commercial purposes. These findings agree with those found by Reardon et al. (2001) where only $8 \%$ of the less progress farmers had access to the market. The lack of market information represents a significant impediment to market access especially for small holders' produce. It substantially increases transaction costs and reduces market efficiency (Mwale, 1998). These findings also agree with the findings of Tadesse and Belay (2007) who found that market disadvantaged small, less educated and less influential farmers.

Membership in social groups: In this study membership in social group was hypothesized as involvement of the respondents in any informal and formal organizations as a member. Farmers who are members of any local organization are more likely to be aware of new information and INRM technologies (Wasula, 2000). Therefore it was expected that there would be positive and significant relationship between membership in social group and the adoption of INRM technologies.

According to Table 7, fifty three (50.5\%) out of 105 adopters were not members of any social group as compared to $49.5 \%$. This could have been the reason for the low adoption of the technologies. This showed that there was a significant relationship between membership in social group and adoption of INRM technologies. According to Blackburn et al. (1982), participation in social groups is important because it indicates the extent of contact, which farmers have with organized groups and other public services and mass media. Groups provide forum for improving dialogue among farmers, thereby providing opportunity for efficient ways of ascertaining consensus on opinion about the relevance of technologies being presented to them (Norman et al., 1989).

Usually participation in the community development activities is perceived as willingness of a person to work together (Wasula, 2000). The relationship between membership in social group and adoption is associated with interpersonal networking and exchanges between adaptors and non-adaptors of technology (Wasula, 2000). This enhances the ability of group members to adopt INRM technologies.

Farmers contact with extension: Contact with extension is an input to improve farmers' performance. It equips farmers with new knowledge and skills, which help them to perform new practices properly. If a farmer has no skill and technical know-how about certain technology, he/she may have less probability of its adoption (Rahmeto, 2007). The skill acquired through extension helps to carry out a new technology
Table 7: Farmer's membership in social groups

\begin{tabular}{lll}
\hline Social group & Adopters $(\mathrm{n}=105)$ & $\begin{array}{l}\text { Non-adopters } \\
(\mathrm{n}=115)\end{array}$ \\
\hline Input supply & $10(9.5 \%)$ & $2(1.7 \%)$ \\
Marketing & $6(5.7 \%)$ & $2(1.7 \%)$ \\
Co-operatives & $2(1.9 \%)$ & $1(0.9 \%)$ \\
Youth groups & $6(5.7 \%)$ & $4(3.5 \%)$ \\
Women groups & $18(17.2 \%) 10(9.5 \%)$ & $16(13.9 \%)$ \\
CBOs & & $7(6.1 \%)$ \\
None & $53(50.5 \%)$ & $83(72.2 \%)$ \\
Total & $105(100 \%)$ & $115(100 \%)$ \\
\hline
\end{tabular}

Table 8: Farmers contact with extension staff

\begin{tabular}{lll}
\hline $\begin{array}{l}\text { Contact with } \\
\text { extension }\end{array}$ & Adopters $(\mathrm{n}=105)$ & $\begin{array}{l}\text { Non-adopters } \\
(\mathrm{n}=115)\end{array}$ \\
\hline Yes & $41(39 \%)$ & $15(13 \%)$ \\
No & $64(61 \%)$ & $100(87 \%)$ \\
Total & $105(100 \%)$ & $115(100 \%)$ \\
\hline
\end{tabular}

effectively and efficiently. If farmers are well trained in new practice, they may not need outside support later. They can properly implement technology package as per the recommendation. The major sources of agricultural information for farmers are extension agents (Tadesse, 2008). The frequency of visits or availability of extension services is perhaps the single variable that emerged significantly in most of the research work on technology transfer and adoption (Asfaw et al., 1997; Kedir, 1998). It was hypothesized that frequency and timely contact with extension workers will increase a farmer's probability of adoption technologies.

In Table 8 the relationship between extension contacts and adoption of INRM technologies was found to be positive. According to Table 9, (64\%) adopters $(87 \%)$ non adaptors had not interacted with extension staff. It can be argued that extension measured in terms of use and type of information is important in adoption of INRM technologies. However it was difficult to rate the extension service in this study in terms of its adequacy and usefulness since the scope of the study was limited to only INRM technologies.

These findings agree with those found by Chitere and Van Doorne (1985) where it was found out that nearly all the farmers in an area previously occupied by European settlers were knowledgeable about improved farming practices. It was also observed that farmers adopt improved farming practices largely because of early exposure to intensive extension education. Several studies also indicated a positive relationship between contact with agricultural information sources and adoption (World Bank, 1993). These also agree with Tadesse (2008) who found that the level of expertise manifested by farmers with intensive extension contact was consistently higher than that of other farmer.

Participating in extension events: In this study, participation in training, demonstration, field day, 
Asian J. Agric. Sci., 6(1): 16-32, 2014

Table 9: Number of times farmers participated in individual visit by extension staff to farmers

\begin{tabular}{|c|c|c|c|c|c|}
\hline \multirow[b]{2}{*}{ No of times $(\mathrm{N})$} & \multicolumn{2}{|c|}{ Adoptors } & \multirow[b]{2}{*}{ No of times $(\mathrm{N})$} & \multicolumn{2}{|c|}{ Non adoptors } \\
\hline & $\mathrm{f}$ & $\%$ & & $\mathrm{f}$ & $\%$ \\
\hline$\overline{0}$ & 80 & 76.2 & 0 & 102 & 88.7 \\
\hline 1 & 10 & 4.8 & 1 & 5 & 4.3 \\
\hline 2 & 8 & 7.6 & 2 & 8 & 7 \\
\hline 3 & 2 & 1.9 & 3 & 0 & 0 \\
\hline 4 & 2 & 1.9 & 4 & 0 & 0 \\
\hline 5 & 1 & 1 & 5 & 0 & 0 \\
\hline$>5$ & 2 & 1.9 & $>5$ & 0 & 0 \\
\hline Total & 105 & 100 & Total & 115 & 100 \\
\hline
\end{tabular}

visit by extension staff, visit to extension staff and agricultural shows were considered as the most important extension events. Participation in extension events is an input to improve farmers' performance. It equips farmers with new knowledge and skills, which help them to perform new practices properly (Rahmeto, 2007). If a farmer has no skill and technical know-how about certain technology, he/she may have less probability of its adoption. The skill acquired through extension helps to carry out a new technology effectively and efficiently. If farmers are well trained in new practice, they may not need outside support later. They can properly implement technology package as per the recommendation (Tadesse, 2008). The sample farmers' participation in different extension events in relation to adoption of INRM technologies is discussed in the following pages. To describe the level of farmers' participation in extension events, farmers were asked eight questions on the various activities bringing together the extension agents and farmers. The responses from the farmers are summarized in Table 9.

The analyzed data indicates that more than half of the farmers $(76.2 \%)$ were never visited by individual extension officers in the past one year while $23.8 \%$ were visited at different level of frequency (Table 9). This could have led to the low adoption of INRM technologies by farmers. There existed a significant relationship between visits made by individual extension agent and adoption of INRM technology. Visits made by extension agent to farmers are an important input to improve farmers' performance. It equips farmers with new knowledge and skills, which help them to perform new practice properly.

The knowledge and skills acquired through training by extension agent helps to carry out a new technology effectively and efficiently. If farmers are well trained in new practice, they may not need outside support later. They can properly implement technology package as per the recommendation (Tadesse, 2008). This result is in complete agreement with findings reported by Rahmeto (2007) who confirmed positive and significant relationship between contact with extension agent and adoption of improved haricot bean technology package.
Other researchers, Girmachew (2005), Abrhaley (2007) and Kidane (2001) also reported similar results.

Group visits by extension agents to farmers: As indicated in Table 10 Seventy nine out of one hundred and five adopters interviewed (65.7\%) were not visited by a group of extension agents while $34.3 \%$ had been visited at different level of frequency in the past one year (Table 10). This could also have led to the low adoption levels. Group visits made by extension agents to farmers are an important input to improve farmers' performance (Tadesse, 2008). It equips farmers with new knowledge and skills, which help them to perform new practice properly. If a farmer has no skill and technical knowledge about a certain technology, he/she may have less probability of its adoption (Tadesse, 2008). The skill acquired through training by extension agents helps to carry out a new technology effectively and efficiently (Rahmeto, 2007). If farmers are well trained in new practice, they may not need outside support later. They can properly implement technology package as per the recommendation (Rahmeto, 2007). This result is in complete agreement with findings reported by Rahmeto (2007) who confirmed positive and significant relationship between contact with extension agent and adoption of improved haricot bean technology package. Other researchers, Girmachew (2005), Abrhaley (2007) and Kidane (2001) also reported similar results.

Visits made to extension officers by farmers: Table 11 clearly indicates that, from the total sampled farmers, 38.1\% adoptors had visited extension officers at different level of frequency while majority of the farmers interviewed $(61.9 \%)$ indicated that they had not visited extension officers in the past one year.

Visits made to extension agents by farmers are an important input to improve farmers' performance (Tadesse, 2008). It equips farmers with new knowledge and skills, which help them to perform new practice properly. If a farmer has no skill and technical knowledge about a certain technology, he/she may have less probability of its adoption (Tadesse, 2008). The skill acquired through training by extension agents helps to carry out a new technology effectively and 
Table 10: Number of times farmers participated in group visits by extension staff to farmers

\begin{tabular}{llllll}
\hline $\begin{array}{l}\text { No of } \\
\text { times }\end{array}$ & $\begin{array}{l}\text { Adoptors } \\
-\mathrm{f}\end{array}$ & $\%$ & $\begin{array}{l}\text { No of } \\
\text { times }\end{array}$ & $\begin{array}{l}\text { Non adoptors } \\
\mathrm{f}\end{array}$ \\
\hline 0 & 69 & 65.7 & 0 & 89 & $\%$ \\
1 & 20 & 19.0 & 1 & 15 & 77.4 \\
2 & 9 & 8.5 & 2 & 7 & 16.3 \\
3 & 1 & 1 & 3 & 1 & 1 \\
4 & 0 & 0 & 4 & 0 & 0 \\
5 & 3 & 2.9 & 5 & 0 & 0 \\
$>5$ & 3 & 2.9 & $>5$ & 0 & 0 \\
Total & 105 & 100 & Total & 115 & 100 \\
\hline
\end{tabular}

Table 11: Number of times farmers participated in visits made to extension officers by farmers

\begin{tabular}{llllll}
\hline $\begin{array}{l}\text { No of } \\
\text { times }\end{array}$ & $\begin{array}{l}\text { Adoptors } \\
\text { f }\end{array}$ & $\%$ & $\begin{array}{l}\text { No of } \\
\text { times }\end{array}$ & $\begin{array}{l}\text { Non Adoptors } \\
\text { f }\end{array}$ \\
\hline 0 & 65 & 61.9 & 0 & 102 & $\%$ \\
1 & 19 & 18.1 & 1 & 5 & 88.7 \\
2 & 8 & 7.6 & 2 & 3 & 2 \\
3 & 5 & 4.8 & 3 & 2 & 1.9 \\
4 & 3 & 2.9 & 4 & 0 & 0 \\
5 & 3 & 2.9 & 5 & 0 & 0 \\
$>5$ & 2 & 1.9 & $>5$ & 0 & 0 \\
Total & 105 & 100 & Total & 115 & 100 \\
\hline
\end{tabular}

Table 12: Number of times farmers participated in on farm demonstrations

\begin{tabular}{llllll}
\hline $\begin{array}{l}\text { No of } \\
\text { times }\end{array}$ & $\begin{array}{l}\text { Adoptors } \\
-\end{array}$ & f & $\%$ & $\begin{array}{l}\text { No of } \\
\text { times }\end{array}$ & $\begin{array}{l}\text { Non Adoptors } \\
\text { f }\end{array}$ \\
\hline 0 & 81 & 77.1 & 0 & 98 & $\%$ \\
1 & 16 & 15 & 1 & 16 & 85.2 \\
2 & 1 & 1 & 2 & 1 & 13.9 \\
3 & 2 & 1 & 3 & 0 & 0 \\
4 & 0 & 0 & 4 & 0 & 0 \\
5 & 0 & 0 & 5 & 0 & 0 \\
$>5$ & 5 & 4.8 & $>5$ & 0 & 0 \\
Total & 105 & 100 & Total & 115 & 100 \\
\hline
\end{tabular}

Table 13: Number of times farmers participated in on station demonstrations

\begin{tabular}{llllll}
\hline \multirow{2}{*}{$\begin{array}{l}\text { No of } \\
\text { times }\end{array}$} & Adoptors & f & $\%$ & $\begin{array}{l}\text { No of } \\
\text { times }\end{array}$ & $\begin{array}{l}\text { Nodoptors } \\
\text { f }\end{array}$ \\
\hline 0 & 73 & 69.5 & 0 & 103 & $\%$ \\
1 & 20 & 19.0 & 1 & 11 & 9.6 \\
2 & 10 & 9.5 & 2 & 1 & 1 \\
3 & 0 & 0 & 3 & 0 & 0 \\
4 & 0 & 0 & 4 & 0 & 0 \\
5 & 0 & 0 & 5 & 0 & 0 \\
$>5$ & 2 & 2.0 & $>5$ & 0 & 0 \\
Total & 105 & 100 & Total & 115 & 100 \\
\hline
\end{tabular}

efficiently. If farmers are well trained in new practice, they may not need outside support later. They can properly implement technology package as per the recommendation (Tadesse, 2008).

On farm demonstrations: Table 12 indicates that only $77 \%$ of total adopters interviewed had not participated in on farm demonstration and while rest $23.9 \%$ indicated that they had attended on farm trial. Demonstration in this study means accepting new practices and put in the field in the form of trial with close supervision of extension agents and then inviting others to see how he/she perform it. In this finding, most farmers who participated in on farm demonstration were of adopter categories. The probable reason for this difference is that extension agents may select the one who accept technology easily to put in to practice according to the recommendation

Demonstration means undertaking field trial with farmers with the aim of creating a learning site for the surrounding farm community (Tedesse, 2008). Demonstration is an important method of extension to create concrete awareness among farm community. This situation may facilitate the adoption process. It is also a means of diffusing information to neighboring farmers to see and then adopt the practice into their farm (Tedesse, 2008). When farmers have a chance to participate in practicing demonstrations they may develop know-how more about the fitness of the package with their socio-economic conditions, this enhances them to take further measures, either to use or not the technological packages. Similar results were identified by Edlu (2006).

On station demonstrations: Table 13 indicates that $69.5 \%$ of total adopters interviewed had not participated in on farm demonstration while only $31.5 \%$ indicated that they had attended on station trial. Demonstration in this study means accepting new practices and put in the field in the form of trial with close supervision of extension agents and then inviting others to see how he/she perform it. In this finding, most farmers who participated in on station demonstration were of the adopter categories. This is in agreement with the findings of Tedesse (2008) who found out that there was a positive relationship between demonstration and adoption of technologies in Ethiopia. This therefore means that Participation in demonstration significantly and positively influenced the adoption of INRM technologies (Tedesse, 2008).

Demonstration means undertaking field trial with farmers with the aim of creating a learning site for the surrounding farm community (Tedesse, 2008). Demonstration is an important method of extension to create concrete awareness among farm community. This situation may facilitate the adoption process (Tedesse, 2008). It is also a means of diffusing information to neighboring farmers to see and then adopt the practice into their farm. When farmers have a chance to participate in practicing demonstrations they may develop know-how more about the fitness of the package with their socio-economic conditions, this enhances them to take further measures, either to use or not the technological packages (Tedesse, 2007). Similar results were identified by Edlu (2006) in a study on extension coverage and utilization by different categories of farmers in Gurage Zone, Ethiopia. 
Attending ASK shows: Table 14 clearly indicates that only $14.4 \%$ of adaptors attended ASK shows at different levels of frequency while majority $85.6 \%$ had not attended any agricultural shows in the past 5 years. They explained that most shows are organized far away from their homes. This therefore means that Participation in ASK shows significantly and positively influence the adoption of INRM technologies. This also means that an increase in farmers' level of participation in extension events like Agricultural Shows will increase adoption and intensity of adoption of INRM technologies (Rahmeto, 2007). Therefore, extension has to give emphasis to such means of transferring agricultural information to farmers. Agricultural Show is one of the most popular methods of transferring technology. Conducting shows is a good way of convincing other farmers to adopt new technology (Tedesse, 2008).

In the Agricultural Shows farmers will get an opportunity to observe how the new technology is put in to practice (Tedesse, 2008). This situation may facilitate the adoption process. The result of this is in agreement with the findings of many authors. For instance, Tesfaye (2006) reported that attendance of Agricultural Shows, field days, on- farm demonstration and training contributed positively to farmers' adoption decision. In the same line, Asfaw et al. (1997) and Yishak (2005) in their studies of determinants of adoption of improved maize technology in Ethiopia and Damote Gala Wareda found that farmers' presence in agricultural Shows and demonstration had positive and significant relationship with adoption. Taha (2007) also reported the same result.

Field days: Table 15 clearly indicates that from the total sample farmers $42.9 \%$ farmers had attended field days at different level of frequency while majority of the farmers $(86.1 \%)$ had not attended any field day in the past one year. The participation of respondents in the field day with varying level of frequency can be observed in Table 10.

Field day is one of the most popular methods of technology transfer. Conducting field days on farmers' field is a good way of convincing other farmers to adopt new technology (Yishak, 2005). In field day neighboring farmers will get an opportunity to observe how the new technology is put into practice in the field. This situation may facilitate the adoption process (Yishak, 2005). The result of this is in agreement with the findings of many authors. For instance, Tesfaye et al. (2001) reported that attendance Agricultural Shows, field days, on- farm demonstration and training contributed positively to farmers' adoption decision. In the same line, Asfaw et al. (1997) and Yishak (2005) in their studies of determinants of adoption of improved maize technology in Ethiopia and Damote Gala Wareda found that farmers' presence in Agricultural Shows,
Table 14: Number of times farmers had attended A.S.K shows

\begin{tabular}{llllll}
\hline \multirow{2}{*}{ No of } & Adoptors & -------- & & \multicolumn{2}{l}{ Non adoptors } \\
Times (N) & $\mathrm{f}$ & $\%$ & Times $(\mathrm{N})$ & $\mathrm{f}$ & $\%$ \\
\hline 0 & 90 & 85.7 & 0 & 100 & 87 \\
1 & 7 & 6.7 & 1 & 7 & 7 \\
2 & 3 & 2.9 & 2 & 8 & 7 \\
3 & 0 & 0 & 3 & 3 & 2 \\
4 & 0 & 0 & 4 & 5 & 4 \\
5 & 0 & 0 & 5 & 0 & 0 \\
$>5$ & 5 & 4.8 & $>5$ & 0 & 0 \\
Total & 105 & 100 & Total & 115 & 100 \\
\hline
\end{tabular}

Table 15: Number of times farmers participated in field days

\begin{tabular}{llllll}
\hline \multirow{2}{*}{$\begin{array}{l}\text { No of } \\
\text { Times }(\mathrm{N})\end{array}$} & Adoptors & $\mathrm{f}$ & $\%$ & No of & \multicolumn{2}{l}{ Non adoptors } \\
\hline 0 & 60 & 57.1 & 0 & 99 & 86.1 \\
1 & 16 & 15.2 & 1 & 11 & 9.6 \\
2 & 9 & 8.6 & 2 & 4 & 3.5 \\
3 & 4 & 3.8 & 3 & 1 & 0.9 \\
4 & 1 & 1 & 4 & 0 & 0 \\
5 & 0 & 0 & 5 & 0 & 0 \\
$>5$ & 15 & 14.3 & $>5$ & 0 & 0 \\
Total & 105 & 100 & Total & 115 & 100 \\
\hline
\end{tabular}

Table 16: Number of times farmers participated in workshops and seminars

\begin{tabular}{llllll}
\hline \multirow{2}{*}{$\begin{array}{l}\text { No of } \\
\text { Times }(\mathrm{N})\end{array}$} & Adoptors & & & \multicolumn{2}{l}{ Non adoptors } \\
\hline 0 & 77 & 73.3 & 0 & -102 & 88.7 \\
1 & 10 & 9.5 & 1 & 7 & 6.1 \\
2 & 7 & 6.7 & 2 & 1 & 1 \\
3 & 9 & 8.5 & 3 & 5 & 4.3 \\
4 & 1 & 1 & 4 & 0 & 0 \\
5 & 1 & 1 & 5 & 0 & 0 \\
$>5$ & 0 & 0 & $>5$ & 0 & 0 \\
Total & 105 & 100 & Total & 115 & 100 \\
\hline
\end{tabular}

field days and demonstration had positive and significant relationship with adoption. Taha (2007) also reported the same result.

Workshops and seminars: Table 16 shows that out of 105 adaptors interviewed $26.7 \%$ had attended workshops and seminars while seventy seven farmers $(73.3 \%)$ did not attended workshops and seminars related to INRM technologies (Table 10).

Training is an important input to improve farmers' performance. It equips farmers with new knowledge and skills, which help them to perform new practice properly. If a farmer has o no skill and technical knowhow about certain technology, he/she may have less probability of its adoption (Tadesse, 2008).

The skill acquired through attendance of workshops and seminars helps to carry out a new technology effectively and efficiently. If farmers are well trained in new practice, they may not need outside support later. They can properly implement technology package as per the recommendation. Concerning farmer's attending training programmes (Rahmeto, 2007). This result is in complete agreement with 
Table 17: Distribution of respondents with respect to radio listening habit

\begin{tabular}{lll}
\hline Frequency of adaptors contact with radio & Frequency & $\%$ \\
\hline Never & 43 & 41 \\
Monthly & 2 & 2 \\
Weekly & 29 & 28 \\
Daily & 31 & 29 \\
Total & 105 & 100 \\
\hline
\end{tabular}

findings reported by Tedesse (2007) who confirmed positive and significant relationship between attendance of workshops and seminars and adoption of improved haricot bean technology package. Other researchers, Girmachew (2005), Abrhaley (2007) and Kidane (2001) also reported similar results.

Mass media exposure: The survey result on mass media exposure of sampled farmers is provided in Table 17.

As indicated in Table 17 in terms of radio listening habit of the farmers in the study area, $41 \%$ of them did not listen to radio programs whereas 2, 28 and $29 \%$ of the respondents have monthly, weekly and daily listening habit (Table 11). Surprisingly, it was noted in FGD that majority of radio listeners in the study area do not pay attention to agricultural programs. Lack of attention to agricultural radio program may be attributed to unfamiliarity of the language and also lack of awareness on the importance of the program. This could be due to the fact that agricultural radio programs were not given top priority by farmers in the study area rather the priority was for other non-agricultural programs. It was also be attributed to lack of favorable attitude towards the program. This therefore confirms (Table 18) that mass media contact had positive and significant relationship with adoption of INRM technologies. The result of this study is consistent with the findings of Kidane (2001) and Getahum (2004) who found out that mass media contact had positive and significant relationship with adoption of improved wheat and maize varieties in Tigray.

The adoption process of agricultural technologies depends on access to information and on the willingness and ability of farmers to use information channels available to them (Tadesse, 2008). The role of information in decision-making process is to reduce risk and uncertainties to enable farmers to make the right decision on adoption of improved agricultural technologies. Mass media play the greatest role in provision of information in the shortest possible time over large area of coverage (Rahmeto, 2007). However, as compared to other communication channels, its effect on behavioral change is weak as it is limited to awareness creation than skill development (Tadesse, 2008).

But, as far as awareness is pre-requisite for behavioral change, still its role cannot be underestimated. Hence, mass media exposure was expected to positively influence adoption and intensity of adoption of INRM technologies (Tadesse, 2008).

Farmers interaction with non governmental organization, local cooperatives and community based organizations: Interaction with development agent is supposed to have a direct influence on the adoption behavior of farmers. When there is contact with development agent, there is the possibility of farmers being influenced to adopt agricultural innovation (Rahmeto, 2007). Table 18 presents results on farmers contact with development organizations.

Interaction with government organization: As indicated in Table 18 the majority $(67.6 \%)$ of total adaptors had not interacted with governmental organizations and the rest $32.4 \%$ had interacted with government organizations at different level of level of frequency. As was expected, interaction with government organization had a significant relationship with the adoption of INRM technologies (Table 18). The government plays a great role in providing information and extension service to farmers (Rahmeto, 2007). A farmer who interacts with government organization has more chance to get information and training in agricultural production (Rahmeto, 2007). Therefore, interaction with government organization was expected to have positive and significant relationship with adoption of INRM technologies (Rahmeto, 2007).

Table 18: Farmer's interaction with various organizations

\begin{tabular}{|c|c|c|c|c|c|c|c|c|c|}
\hline \multirow{3}{*}{ Organization } & & \multicolumn{4}{|c|}{ Adopters } & \multicolumn{4}{|c|}{ Non adapters } \\
\hline & & \multicolumn{4}{|c|}{ Interaction } & \multicolumn{4}{|c|}{ Interaction } \\
\hline & & Never & Often & Rarely & Total & Never & Often & Rarely & Total \\
\hline \multirow[t]{3}{*}{ Government Organization } & $\mathrm{N}$ & 71.0 & 27 & 7.0 & 105 & 97 & 15 & 3 & 115 \\
\hline & $\%$ & 67.6 & 25.7 & 6.7 & 100 & 84.3 & 11 & 2.6 & 100 \\
\hline & $\mathrm{N}$ & 72.0 & 26 & 7.0 & 105 & 100 & 26 & 4 & 115 \\
\hline \multirow[t]{2}{*}{$\mathrm{NGO}$} & $\%$ & 68.6 & 24.8 & 6.7 & 100 & 86.9 & 9.5 & 3.5 & 100 \\
\hline & $\mathrm{N}$ & 88.0 & 5 & 2.0 & 105 & 98 & 7 & 10 & 115 \\
\hline \multirow[t]{2}{*}{ Local cooperative } & $\%$ & 93.3 & 4.8 & 1.9 & 100 & 85 & 6.1 & 8.7 & 100 \\
\hline & $\mathrm{N}$ & 59.0 & 28 & 18.0 & 105 & 88 & 15 & 12 & 115 \\
\hline $\mathrm{CBO}$ & $\%$ & 56.2 & 26.7 & 17.1 & 100 & 76.5 & 13 & 10.4 & 100 \\
\hline
\end{tabular}


The significant relationship between membership and interaction with government organizations and adoption is an indication for the importance of government organizations in supporting agricultural production. Farmers who had interacted with government organizations were found to be better in access to and use of extension information (Tadesse, 2008). This agrees with prior expectation and confirms the study carried out by Nkonya et al. (1997) who found out that there was positive and significant relationship between interaction with development agent and adoption of improved maize seed and fertilizer in North Tanzania.

Interaction with cooperative: As was expected, the membership of cooperative society and interaction with cooperative society had a significant relationship with the adoption of INRM technologies (Table 18). Ninety eight farmers $(93.3 \%)$ were found to be non-members of any local cooperative society and had never interacted with any local cooperative society and the rest $6.7 \%$ were reported to be members and had interacted with cooperative societies at different level of level of frequency.

Cooperatives serve as an important source of rural credit and input supply. A farmer who is a member or service cooperative has more chance to get credit. Therefore, the membership in cooperative and interaction with cooperative has been observed to have positive and significant relationship with adoption of INRM technologies (Tadesse, 2008).

The significant relationship between membership and interaction with cooperative society and adoption is an indication for the importance of rural financial institutions in supporting agricultural production. In previous studies Cooperative members were found to be better in access to and use of credit services (Tadesse, 2008). This agrees with prior expectation and confirms the study carried out by Nkonya et al. (1997) who found out that there was positive and significant relationship between interaction with development agent and adoption of improved maize seed and fertilizer in North Tanzania.

Interaction with non-governmental organization: As was expected, interaction with non-governmental organization had a significant relationship with the adoption of INRM technologies (Table 18). The majority $(68.5 \%)$ of total adaptors had not interacted with non-governmental organizations and the rest $31.5 \%$ had interacted with non-governmental organizations at different level of level of frequency.

Non-governmental organizations play a great role in providing information and extension service to farmers. A farmer who interacts with non governmental organization has more chance to get information and training in agricultural production (Tadesse, 2008).
The significant relationship between interaction with non governmental organizations and adoption is an indication for the importance of non governmental organizations in supporting agricultural production. Farmers who had interacted with non governmental organizations were found to be better in access to and use of extension information. Key informants from public institutions identified NGOs such as CARE, CMAD, GIZ and AEP as some of the NGOs that have programmes in the Division. This agrees with prior expectation and confirms the study carried out by Nkonya et al. (1997) who found out that there was positive and significant relationship between interaction with development agent and adoption of improved maize seed and fertilizer in North Tanzania.

Interaction with community based organization: As was expected, interaction with community based organization had a significant relationship with the adoption of INRM technologies (Table 18). The majority $(56.2 \%)$ of total adaptors had not interacted with community based organizations and the rest $43.8 \%$ had interacted with community based organizations at different level of levels. Community based organizations play a great role in providing information and extension service to farmers. A farmer who interacts with community based organization has more chance to get information and training in agricultural production. Therefore, interaction with community based organization was hypothesized to have positive and significant relationship with adoption of INRM technologies (Tadesse, 2008).

The significant relationship between interaction with community based organizations and adoption is an indication for the importance of community based organizations in supporting agricultural production. Farmers who had interacted with community based organizations were found to be better in access to and use of extension information (Rahmeto, 2007). This agrees with prior expectation and confirms the study carried out by Nkonya et al. (1997) who found out that there was positive and significant relationship between interaction with development agent and adoption of improved maize seed and fertilizer in North Tanzania.

Relationship between socio-cultural factors and adoption level of INRM technologies: The farmers were asked to respond to a set of questions on the socio-cultural factors that have influence on the adoption of INRM technologies. The factors included leadership status, perception, cultural beliefs, cultural traditions and social norms.

\section{SUMMARY, CONCLUSION AND RECOMMENDATIONS}

Summary: This study was set to investigate the institutional determinants of the adoption of INRM 
technologies by small scale farmers in Kenya's Ndhiwa division. The study was necessary because the performance of the agricultural sector has remained low even after the introduction of INRM technologies. The low adoption levels of these technologies affect the overall production of crops in the area. The study employed cross sectional survey design with an expost-facto approach. Data was collected from a sample of 220 farmers from different locations in the area.

The variations in adoption of the package practices among farmers were assessed from the point of view of various factors which influence farmers' adoption behavior. Most of the variables assumed to influence the adoption behavior were significantly associated with the adoption and degree of adoption of INRM technologies.

Adoption of manure use was better than the adoption of agro forestry, fertilizer use and use of stoverlines though the adoption of all these remained low.

Among the institutional factors the study confirmed that mass media exposure, access to credit, access to quality to quality inputs, access to market and participation in extension events were found to be significantly related with adoption of INRM technologies.

Conclusion: In view of the data analysis and results shown in chapter four it can be concluded as follows:

- Close to $47 \%$ of the farmers in the study area had adopted INRM technologies while close to $52 \%$ of the farmers had not adopted INRM technologies. This was low given that the technologies have been in existence for more than three years.

- Farmers' access to credit does influence the use of INRM technologies and therefore it is related to the adoption of INRM technologies, a finding which concurs with studies cite earlier. It requires that farmers that farmers are educated on new technologies governing the crops production.

- Regarding adoption of the INRM technologies in relation to selected variables, a number of factors showed varying relationship. For instance tenancy status seemed not to influence farmer's adoption of INRM technologies while access to quality inputs, access to market, contact and with extension seemed to influence the farmer's adoption of INRM technologies in the study area.

- Farmers mentioned a number of constraints that act as deterrents to adoption of INRM technologies. These include: Lack of inputs, lack of credit and of awareness of INRM technology information.

- The most dramatic change that will influence adoption of INRM technologies is the development of institutional strategies that target small-scale farmers so that potential adopters can adopt the INRM technologies to improve production.
- The other problem in the study area is unplanned production of crops. Almost all farmers found in the study area plant crops and trees crops in the same planting dates. The excess amount of harvest reaches at the same time and this situation creates favorable condition for middle men to set low price on the harvest. Therefore the extension service sector has to take in to consideration this issue and training is needed for farmers to stagger the planting time. Staggering the planting time will lead to extended supply of produce in the market and keep up the market price.

Recommendations: The following recommendations have been suggested from the findings and conclusions of the study:

- Extension agents should consider improving their level of participation in joint activities. They should also consider improving the number of visits to farmer's field to understand the farmers' conditions better.

- Plenty of extension effort is needed in dissemination of INRM technologies information. This effort could be in terms of field days, farm visits, agricultural shows, holding demonstrations that focus on new technologies.

- Ways and means of encouraging small-scale farmers to adopt INRM technologies without necessarily relying on government subsidies should be developed by encouraging them to form small groups with revolving funds.

- Researchers should encourage multistage development of technologies that favor small-scale farmers since they form a large proportion of farmers in Kenya today.

- Institutional strategies should be developed to favor young and women farmers since they are the majority who engage in agricultural activities on the ground.

- Farmers should be sensitized on socio-cultural aspects that hinder adoption of technologies in the division.

- Producers and extension agents need adequate skills in production management practices starting from seed selection to post harvest technologies suitable at their level. Marketing principles, bargaining skills, business planning, quality management and post harvest handling of agricultural products are some of the interventions needed in the study area.

\section{REFERENCES}

Abrhaley, G., 2007. Farmers' perception and adoption of integrated striga management technology in Tahtay Adiabo Woreda, Tigray, Ethiopia. Unpublished M.Sc. Thesis, Haramaya University, Haramaya, Ethiopia, Kenya. 
Ajayi, O.C., S. Franzel, E. Kuntashula and F. Kwesiga, 2003. Adoption of improved fallow technology for soil fertility management in Zambia: Empirical studies and emerging issue. Agro Forest. Syst., 59(3): 317-326.

Ary, D., L.C. Jacobs and A. Ravavier, 1979. Introduction to Research in Education. Rinehart and Winston Publishers, Holt, New York.

Asfaw, N., K. Gungal, W. Mwangi and S. Beyene, 1997. Factors affecting adoption of maize production technologies in Ethiopia. Ethiopian J. Agric. Econ., 2: 52-69.

Barret, C.B., F. Place and A.A. Aboud, 2002. Natural Resource Management in African Agriculture: Understanding and Improving Current Practices. CABI Publishers, Oxford.

Blackburn, D.J., G.L. Brinkman and H.C. Driver, 1982. Understanding Behaviour and Economic Characteristics in Working with Operations of Small Farms: A Case Study in Ontario Canada. John Wiley, New York.

Chitere, P.A. and J.H. Van Doorne, 1985. Extension education and farmers performance in improved crop farming in Kakamega District. Agr. Admin. Ext., 18(2).

Edlu, B., 2006. Extension program coverage and utilization by different categories of farmers in Enemore and Eneworeda, Gurage Zone, Ethiopia. Unpublished M.Sc. Thesis, Hmaraya University, Haramaya, Ethiopia.

FAO (Food and Agriculture Organization), 1986. Consultation on irrigation in Africa: Proceedings of the Consultation of Irrigation in Africa. FAO, Rome.

FAO (Food and Agriculture Organization), 2004. Scaling Soil Nutrient Balance: Enabling Mesolevel Applications for African Realities. FAO, Rome.

Franzel, S., R. Coe, P. Cooper, F. Place and S.J. Sherr, 2001. Assessing the adoption potential of agro forestry practices in sub-Saharan Africa. Agric. Syst., 69: 37-62.

Getahum, D., 2004. Assessment of factors affecting adoption wheat technologies and its impact. The case of Hula Woreda, Ethiopia. Unpublished M.Sc. Thesis, Alemaya University, Alemaya, Ethiopia.

Girmachew, P., 2005. Determinants of adoption of soil and water conservation practices in the environs of Simen mountains National Park, Ethiopia. Unpublished M.Sc. Thesis, Alemaya University, Alemaya, Ethiopia.

Government of Kenya, 2001a. National Agricultural and Livestock Extension Programme. Implementation Framework, MOARD, Nairobi.

IFAP (International Federation of Agricultural Producers), 1995. Negotiating Linkages: Farmers' Organizations, Agricultural Research and Extension. IFAD, Nairobi, Kenya, pp: 40.
Jaetzold, R. and H. Schmidt, 1982. Farm Management Handbook of Kenya. Vol. II: Natural Conditions and Farm Management Information Part A: West Kenya, Nyanza and Western Provinces. Kenya Ministry of Agriculture and the German Agricultural Team of GTZ, Nairobi, Kenya, pp: 397.

Kedir, B., 1998. The role of SG2000 project credit system in the adoption of wheat technologies by smallholder farmers in Ethiopia. The case of Hetosa district. Unpublished M.Sc. Thesis, Sokoine University, Morogoro, Tanzania.

Kidane, G., 2001. Factors influencing the adoption of new wheat and maize varieties in Tigray, Ethiopia. Unpublished M.Sc. Thesis, Alemaya University, Alemaya, Ethiopia.

Legesse, D., 1992. Analysis of factors influencing adoption and the impact of wheat and maize technologies in Aris Nagele, Ethiopia. Unpublished M.Sc. Thesis, Alemaya University, Alemaya, Ethiopia.

Mesfin, A., 2005. Analysis of factors influencing adoption triticale and its impact the case of Farta Wareda, Ethiopia. Unpublished M.Sc. Thesis, Alemaya University, Alemaya, Ethiopia.

Mugeta, S., 2000. Uptake and response of rice to nitrogen and phosphorus fertilizer under rainfed lowland condition of the Fogera plain, Northern Ethiopia. M.Sc. Thesis, Alemaya University, Ethiopia.

Mwale, S.M., 1998. Integrating Food and Environmental Security in the Greater Horn of Africa: A Preliminary Institutional Stakeholder Analysis. IUCN and WRI, pp: 67-79.

Nassiuma, D.K., 2000. Survey Sampling: Theory and Methods. Nairobi University Press, Nairobi.

Ndiema, A.C., 2002. Factors affecting the adoption of wheat production technologies by farmers in Njoro and Rongai Divisions of Nakuru Districts, Kenya. Unpublished M.Sc. Thesis, Egerton University, Njoro, Kenya.

Nkonya, E., T. Schroeder and D. Norman, 1997. Factors affecting adoption of improved maize seed and fertilizer in northern Tanzania. J. Agric. Econ., 48(1): 1-12.

Norman, D., D. Baker, G. Heinrich, C. Joha, Maskiara and F. Worman, 1989. Farmers Groups for Technology Development, Experiences in Botswana, in Chambers: Farmers Innovation and Agricultural Research. Intermediate Technology Publication, London.

Nye, P.H. and D.J. Greenland, 1960. The Soil Under Shifting Cultivation. Technical Communication No. 51. Commonwealth Bureau of Soil, Commonwealth Agricultural Bureaux, Harpenden, UK. 
Odera, M.M., S.K. Kimani and F. Musembi, 2000. Factors influencing adoption of integrated use manure and inorganic fertilizer in central highlands of Kenya. Proceeding of the 7th Biennial Scientific Conference on Collaboration and Participatory Research for Sustainably Improved Livelihoods. Kenya Agricultural Research Institute (KARI), Nairobi, Kenya, pp: 58-64.

Okuro, J.O., F.M. Muriithi, W. Mwangi, H. Verjuikl, M. Gethi and H. Groote, 2002. Adoption of Maize Seed and Fertilizer Technologies in Embu District, Kenya. CIMMYT and Kenya Agricultural Research Institute (KARI), Mexico.

Pfister, F., H.P. Bader, R. Scheider and P. Buccini, 2005. Dynamic modeling of resource management for farming systems. Agric. Syst., 86: 1-28.

Phiri, D., S. Franzel, P. Mafongoya, I. Jere, R. Katanga and S. Phiri, 2003. Who is using new technology? The association of wealth status and gender with the planting of improved tree fallows in Eastern Province Zambia. Agric. Syst., 79: 131-144.

Pieri, C.J., 1989. Fertility of Soils. A Future for Farming in West African Savannah. SpringerVerlag, Berlin.

Place, F.F., C.B. Barret, H.A. Freeman, J.J. Ramisch and B. Vanlauwe, 2003. Prospects for integrated soil fertility management using organic and inorganic inputs: Evidence from smallholder African agricultural systems. Food Policy, 28: 365-378.

Rahmeto, N., 2007. Determinants of improved haricot bean production package in Alaba special wored, Southern Ethiopia. Unpublished M.Sc. Thesis, Hamaraya University, Hamaraya, Ethiopia.

Reardon, T., C.B. Barret, V. Kelly and K. Savadogo, 2001. Sustainable Versus Unsustainable Agricultural Intensification in Africa: Focus on Policy Reforms and Market Conditions. In: Lee, D.R. and C.B. Barret (Eds.), Tradeoffs or Synergies? Agricultural Intensification, Economic Development and the Environment. CABI Publishing, Oxford.

Sanchez, P.A., B. Jama, A.I. Niang and C.A. Palm, 2001. Soil Fertility, Small Farm Intensification and the Environment in Africa. Trade Offs or Synergies? Agricultural Intensification, Economic Development and the Environment. CABI Publishing, Wallingford.

Sheikh, A.D., T. Rehman and C.M. Yates, 2003. Logit models for identifying the factors that influence the uptake of new "no tillage" technologies by farmers in the rice-wheat and cotton-wheat farming. Agric. Syst., 75: 79-95.

Smaling, E.M.A., J.J. Stoorvogel and P.N. Windmeijer, 1993. Calculating soil nutrient balance in Africa at different scales: II. District scale. Fertil. Res., 35: 237-250.
Tadesse, M. and K. Belay, 2007. Determinants of Fertilizer Use in Gununo Area, Ethiopia. In: Tesfaye, Z., D. Legesse and A. Dawit (Eds.), Proceedings of Agricultural Technology Evaluation Adoption and Marketing. Workshop held to Discuss Results of 1998-2002, August 6-8, pp: 21-31.

Tadesse, T., M. Haila, G. Seney, C. Knutson and B.D. Wardlow, 2008. Building integrated drought monitoring and food security systems in SubSaharan Africa. Nat. Resour. Forum, 32: 303-316.

Taha, M., 2007. Determinants of the adoption of improved onion production package in Dugda Bora district, East Shoa, Ethiopia. Unpublished M.Sc. Thesis, Hamaraya University, Hamaraya, Ethiopia.

Teressa, A., 1997. Factors influencing adoption and intensity of use of fertilizer: The case of Lume district, Central Ethiopia. Quart. J. Int. Agric., 36: 173-187.

Tesfaye, W., 2006. Analysing factors affecting adoption of rain water harvesting technology in Dugda Bora district, East Shoa, Ethiopia. Unpublished M.Sc. Thesis, Hamaraya University, Hamaraya, Ethiopia.

Tesfaye, Z., T. Bedassa and T. Shiferaw, 2001. Determinants of high yielding maize technology adoption. Empirical evidence from Southwestern Oromia. Research Report No. 38. Ethiopia Agricultural Research Organization (EARO), pp: 39.

Van der Bosch, H., A. De Jager and J. Vlaming, 1998. Monitoring nutrient flow and economic performance in African farming systems (NUTMON). III. Monitoring nutrient flows and balancing in three districts in Kenya. Agric. Ecosyst. Environ., 71: 65-82.

Vanlauwe, B., 2004. Integrated Soil Fertility Management Research at TSBF: The Framework, the Principles and their Application. Managing Nutrient Cycles to Sustain Soil Fertility in SubSahara Africa. Academy Science Publishers, Nairobi.

Vanleuw, B. and K.E. Giller, 2006. Popular myths around soil fertility management in sub-Saharah Africa. Agric. Ecosyst. Environ., 116: 34-46.

Wasula, S.L., 2000. Influence of Socio-economic factors on adoption of agroforestry related technology. The case of Njoro and Rongai Districts, Kenya. Unpublished M.Sc. Thesis, Egerton University, Njoro, Kenya.

World Bank, 2003. Reaching the Rural Poor: A Renewed Strategy for Rural Development. The World Bank, Washington DC.

World Bank, 1993. Rural Women and Agricultural Extension in the Sahel. Findings, Africa Region. Number 46, The World Bank, Washington D.C. Retrieved from: http://www.worldbank.org/afr/ findings/English/find 46.htm. 
Yates, R.A. and A. Kiss, 1992. Using and Sustaining Africa's Soils. Agriculture and Rural Development Series No. 6. World Bank, Washington, D.C.

Yishak, G., 2005. Determinants of adoption improved maize technology in Damote Gale Woreda, Wolaita, Ethiopia. Unpublished M.Sc. Thesis, Alemaya University, Alemaya, Ethiopia.
Young, A., 1997. Agro Forestry for Soil Conservation. CAB International, Oxford. 